we be able to preserve the objectives of science and technology policy, such as improving the quality and internationalization of research; or are we just looking at conventional questions of regional balance and educational needs?"

Ormala argues that supporting innovation need not be politically motivated. "What we are trying to create is not dirigisme" he says. "It is politically neutral, but it is not indifferent on the question of industrial renewal - which means that we need more R\&D, more education and training, and more risk financing."

According to Ormala, the biggest problem facing science in Finland is how to reorganize research as an integral part of the European system. "If you look at R\&D in Finland, it is not international, it is very domestic, and in many fields it is of moderate quality," he says. "We have to learn that it is not sufficient to be good here; you have to be good at the international level."

Awareness of the value of international cooperation in stimulating the quality of domestic research has been one of the main reasons behind Finland's recent departure from its traditional neutrality and its increasing willingness to participate in international research projects. "If you are trying to get research money from Brussels, then you must be good." says Paavo Uronen, professor of physics and vice-rector of the Helsinki University of Technology. "Otherwise you will not have research groups which will survive under international competition. Competition will ensure that the quality of research is good enough."

Finland became a full member of CERN (the European Laboratory for Particle Physics), for example, in 1991. And it is applying for full membership of the European Space Agency, of which it is an associate member. "For a small country these programmes mean a lot; we have been very isolated in the past, and it will certainly change the climate", says Helander at the academy.

Both decisions have been actively promoted by politicians keen to see Finland integrated into Europe. But both have been controversial in the scientific community. In both cases, the subscriptions will come, de facto, from the domestic research budget; and there are those who argue that, in strictly economic terms, better value might be obtained from pursuing other goals.

So far, however, despite the fears of a shift away from investment in basic research and into joint European programmes, there has been little protest about the impending cuts from among the scientific community. "The general reaction has been calm," says academy president Tanskanen. "The economic situation is so bad that everything has to be compared to that".

\title{
Universities tighten their belts
}

AFTER several decades of rapid breeding, the Finnish university system has so many children that its doesn't know what to do. As a result of intensive regionalization, the country now boasts 17 universities, 3 art schools and 22 newly designated polytechnics; that makes a total of more than 40 university-level institutions in a nation of only 5 million inhabitants.

In the good times, this was not a problem. As late as 1987, the government - buoyed by the apparent strength of the economy - committed itself to increasing spending on universities by 15 per cent in real terms for the following four years. This ambitious goal has almost been met. Government spending on universities rose from Fmk3.23 billion ( $£ 425$ million) in 1987 to Fmk4.78 billion in 1991 in constant prices, an increase of almost 50 per cent. The money has allowed all universities to buy research equipment and fill new teaching positions and professorial chairs.

Now the day of reckoning has arrived. With the collapse of the Finnish economy, the government has higher education in its sights as it seeks to put a tight squeeze on public spending. It has already announced a 10 per cent cut in the amount of money the universities will receive next year, and 5 per cent cuts in each of the following two years. It is also planning a major restructuring of the university system, due to be announced next April, which could mean some of the smaller universities giving up a significant part of their research activities.

Part of the budget reductions will come from the reduction in public sector salaries. But reductions elsewhere will be much larger, resulting in major cuts in research budgets and running costs, and the deferment of capital spending.

The University of Helsinki, for example, founded 350 years ago and the largest in the country, is cutting its spending on scientific equipment by 27 per cent next year and its operating expenses, including journal subscriptions and laboratory materials, by 14 per cent.

To Risto Ihamuotila, professor of agricultural science and recently appointed rector of the university, the basic problem is straightforward. "We have too many universities," he says, and he has publicly proposed reducing the total by about half. But Ihamuotila, a former chairman of the National Council for Higher Education, admits that such a solution would be unacceptable in political circles. The alternative now gathering support among many university administrators is for greater selectivity and concentration of both teaching and research resources.

"The only way that our science and technology will survive at an international level is to have centres of excellence," says Paavo Uronen, professor of physics and vice-rector of the Helsinki University of Technology. "Our system was expanded too fast and in too many places. Now each university wants to stay independent and keep their activities."

Uronen would like to see each university boasting its own strong field. Such a proposal is widely expected to be endorsed next year by the Ministry of Education. The idea is that universities should concentrate on groups that are particularly strong in research, and organize their finances in such a way that support for these groups is increased where possible from industry - and that money for less productive groups should be decreased or eliminated.

Many, however, already face the problem that, with the current economic

\section{Helsinki's rector Risto Inamuotila bridles at the 'public sector' treatment}

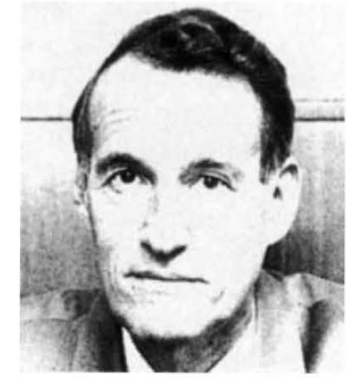

recession, there has been a significant decline in the amount of money that private industry is prepared to provide to university research groups. This is particularly difficult for the newly created universities of technology.

Reduced government spending is also concerning the Academy of Finland. "If universities cut down, then we have to cut down too," says Elisabeth Helander, the academy's research director. "The problem is that figures from the universities show that about half of the professors will retire in the five years either side of the end of the century. That means that it is important to keep young people in the system that you can recruit from; a lack of funding will make this difficult."

Ihamuotila at Helsinki University claims that the major problem now facing universities is that they are being treated as part of the public sector, and are being given identical treatment to other parts of this sector. "We think that universities are always needed, and that our task is even more important than it was earlier," he says. "Our economic life is based too much on the metal and forestry industries; in the future we will need more high-technology industries, based on electronics and the biosciences, and it is support for these type of areas that the universities can provide". 